Egyptian J. of Nutrition Vol. XXXVI No. 2 (2021)

\title{
Therapeutic potential of low-fat yogurt \\ supplemented with Dried Nabaq fruit (Zizyphus \\ spina-christi $L$ ) on hyperglycemia in \\ streptozotocin-induced diabetic rats.
}

\section{Atwaa E.H1. , Hanan A. Radwan2, Hanan S. Shalaby3 and Ghada M. El-Araby1}

1- Food Sci. Dept., Fac. Agric., Zagazig Univ., Egypt.

2- Department of Home Economics, Faculty of Specific Education, Zagazig University, Egypt.

3- Food Science Department, (Rural Home Economics) Faculty of Agriculture, Zagazig University, Egypt.

\section{Abstract}

Nabaq (Zizyphus spina-christi L) fruit has a rich composition of bioactive components such as phenolic, flavonoids, dietary fiber, minerals and vitamins. The study was carried out to evaluate the effect of supplementation dried Nabaq fruit on the physicochemical, rheological and sensory properties of low fat yoghurt ( $1 \%$ fat). Dried Nabaq fruit was added to low fat milk yoghurt at ratios of 2 and 4 $\%$.Results showed that gradual increase in $\mathrm{pH}$, dietary fiber, viscosity, phenolic content and antioxidant activity values of low fat yoghurt as dried Nabaq fruit ratio was increased. On the other hand, the acidity and synersis were decreased as the ratio of dried Nabaq fruit was increased. Low fat yoghurt that containing of $4 \%$ of dried 


\section{Atwaa E.H. , Hanan A. Radwan, Hanan S. Shalaby and Ghada M. El-Araby}

Nabaq fruit were the highest of physicochemical, acceptability sensory and rheological properties than the other treatments. Low fat yoghurt fortified with $4 \%$ dried Nabaq fruit were evaluated as hypoglycaemic agent streptozotocin-induced diabetic rats. Forty male rats were divided into 5 groups as follows: Group (1) nontreated non-diabetic rats (negative control). Group (2) diabetic rats (received Streptozotocin (STZ), $60 \mathrm{mg} / \mathrm{Kg} \quad \mathrm{BW}$ ) (positive control).Group (3) diabetic rats treated with $20 \%$ low fat yoghurt without any additives.

Group (4) diabetic rats treated with $20 \%$ low fat yoghurt fortified with $4 \%$ dried Nabaq fruit. Group (5) diabetic rats treated with Meglitinides.The treatment of diabetic rats with low fat yoghurt containing dried Nabaq fruit showed a significant decreases $(p<0.001)$ in levels of blood glucose, malondialdehyde (MDA), low density lipoprotein (LDL), cholesterol (CL), Triglyceride (TG), AST, ALT, ALP, Creatinin, Uric acid and Urea and increased $(p<0.001)$ Insulin, high density lipoprotein (HDL) and total antioxidant capacity (TAC) in comparison to diabetic control rats. Thus, the study demonstrates that dried Nabaq fruit can be used as a source of phenolic compounds and dietary fiber in low fat yoghurt which enhanced its nutritional value, rheological and sensory properties and possess a hypoglycemia effect. 


\section{Introduction}

Diabetes mellitus (DM) is a metabolic disorder that is characterized by an abnormal long-term increase in plasma glucose levels. Diabetes is mainly classified into four types, i.e., type I diabetes (T1DM), type II diabetes (T2DM), gestational diabetes, and specific types of diabetes due to other causes (American Diabetes Association, 2019).

Many factors, such as insulin deficiency or resistance as well as altered carbohydrate, protein, and fat metabolisms, are usually the reasons for high blood glucose levels leading to DM. Chronic hyperglycemia related to diabetes is often associated with many other complications, such as cardiovascular, dermatological, neurological, renal, retinal, and nerve diseases. Diabetes is one of the most common chronic diseases, and it has shown an increasing rate of occurrence over the past decade (Bullard et al., 2018).

According to the World Health Organization (WHO), the total number of people with diabetes worldwide substantially increased from 108 million in 1980 to 422 million in 2014 (World Health Organization, 2016). Along with diabetes, the incidence of other metabolic diseases, such as hyperlipidemia, is also increasing rapidly (Karr, 2017) 


\section{Atwaa E.H. , Hanan A. Radwan, Hanan S. Shalaby and Ghada M. El-Araby}

In type II diabetes mellitus, progressive decline in insulin action referred as insulin resistance and pancreatic $\beta$-cell dysfunction leads to increased levels of blood glucose (Srinivasan et al., 2005). A major risk factor for insulin resistance is obesity, which is generally caused by a western style high fatty diet and physical inactivity (Zheng et al., 2012).

The development of insulin resistance in obesity exhibits accelerated lipolytic activity with increased release of free fatty acids (FFA) into the portal circulation. The FFA may be cytotoxic by inducing lipid peroxidation and hepatocyte apoptosis resulting in fatty liver disease. Further, studies have shown that both obesity and type II diabetes impair insulin-induced suppression of glycogenolysis and gluconeogenesis. The current treatment for type II diabetes includes insulin and oral hypoglycemic drugs such as biguanides, sulfonylurea derivatives, thiazolidinediones and a-glucosidase inhibitors. These medications have side effects, e. g. thiazolidinediones induce obesity, osteoporosis and sodium retention; sulfonylurea derivatives can lead to incidences of severe hypoglycemia, whereas biguanides like metformin put patients at risk of developing lactic acidosis (Hamza et al .,2010 and Bandawane et al. ,2020).

Further, the oral monotherapy with lifestyle changes is not sufficient for most of the diabetic patients and requires various oral combinations or addition of insulin (Stumvoll et al., 2005). Thus, there is an increasing need to search for effective antidiabetic agents 
Egyptian J. of Nutrition Vol. XXXVI No. 2 (2021)

exhibiting fewer side effects. As an alternative, large number of population is trying to rely on plant-based remedies for management of this metabolic disorder. (Bandawane et al., 2020).

Free radical production is stimulated by hyperglycemia, leading to cell damage. In living organisms, oxidation is an essential process during the production of energy for use as fuel for biological processes. However, the increase in the formation of free radicals such as reactive oxygen species (ROS) plays a crucial rule in the pathophysiology of several diseases such as diabetes, cancer, and cardiovascular disease. Oxidative stress may also play a role in metabolic syndrome, which is indicated by the presence of several oxidative biomarkers (Končić et al., 2010). In addition, the body's stress response may result in the progression or acceleration of numerous diseases related to oxidative stress (Hemmati et al., 2016).

Antioxidants can delay or inhibit the oxidation of lipids or other molecules by inhibiting the initiation or progression of oxidizing chain reactions. Previous studies have demonstrated that antioxidants can reduce markers of oxidative stress in both experimental and clinical models of diabetes. The redox status is disrupted in both type 1 and type 2 DM due to hyperglycemia, resulting in stress mediated cellular injury (Hoshyar et al., 2015).

Recently, consumers have trend to use of reduced fat dairy products but the functional role of fat in fermented milk causes enhancement of rheological and sensory characteristics (Pakseresht et al., 2019). However, since using plant natural additives in 


\section{Atwaa E.H. , Hanan A. Radwan, Hanan S. Shalaby and Ghada M. El-Araby}

production of low-fat fermented dairy products given some advantages such as a substitute for fat and solves some technological problems, probiotic or synbiotic effect, bulking agent or micronutrient premixes, (Atwaa et al., 2020).

Ziziphus spina-christi (family Rhamnaceae, order of Rosales) tree cultivated in the East and South areas of Asia and the Middle East region (Yossef et a.l, 2011). Generally, in Arabic, the fruits have been given the same tree name (Saied et al., 2008). In most Arabic countries such as in Saudi Arabia and Egypt, Ziziphus spina-christi tree was commonly named Nabaq (related to the Lote-trees of the Quran) while the fruit was called Nabka (Michel, 2011 and Saaty, 2019). The plant has been utilized in traditional medicine in Middle East, mainly the fruits, seeds, leaves, roots and bark (Asgarpanah and Haghighat, 2012). The fruit of Ziziphus spina-christi consider a rich source for important dietary components (Hamza et al., 2015 and Temerk et al., 2017)The fruit also contains high amount of vitamin $\mathrm{C}$ which is a considerably larger amount compared to those present in strawberry, orange, and grape (38 $\mathrm{mg})$.

The fruits has rich amount of polyphenols (Alhakmani et al., 2014, Hashem and Abd El-Lahot, 2021). Phenolic compounds are important natural antioxidants that possess scavenging activity against free radicals (Weidner et al., 2012). Sider fruit is used to heal several ailments such as liver complaints, urinary issues, digestive syndromes, weakness, obesity, diabetes, skin infection, appetite loss, 
Egyptian J. of Nutrition Vol. XXXVI No. 2 (2021)

fever, bronchitis, pharyngitis, anemia, insomnia and diarrhea (AlGhamdi et al., 2019).

The aim of this study to determine of physicochemical, antioxidant activity and total phenolic content of Nabaq fruit and evaluation the effect of added dried Nabaq fruit on physicochemical, rheological, and sensory properties of low fat yoghurt and to investigate the role of yoghurt fortified with dried Nabaq fruit as hypoglycemia agents.

\section{Materials and Methods}

\section{Materials}

Three $\mathrm{kg}$ of the fresh Nabaq fruits (Ziziphus spina- christi), were purchased from the local market, Sharkia, Egypt. The fresh Nabaq fruits (Fig. a) were cleaned with tap water and carefully separated into pulps and seeds using astainless-steel knife. Fruit pulp was dehydrated at $45^{\circ} \mathrm{C}$ for $12 \mathrm{~h}$ in a thermostatically controlled hot air oven. The dehydrated pulp was ground using a milling machine (Culatti Hammer Mill DCFH 48, Germany), then packed in air-tight Kilner jar and stored in a refrigerator $\left(4^{\circ} \mathrm{C}\right)$ until used. Fresh buffalo's milk (3\% fat) was obtained from Dairy Technology Unit, Food Science Department, Faculty of Agriculture, and Zigzag University, Egypt. Starter Cultures: Streptococcus salivarius subsp. thermophilus EMCC104 and Lactobacillus delbruekii subsp. bulgaricus EMCC1102 Were obtained from the Microbiological Resources Center (MIRCEN), Faculty of Agric. Aim Shams Univ., 


\section{Atwaa E.H. , Hanan A. Radwan, Hanan S. Shalaby and Ghada M. El-Araby}

Egypt. DPPH reagent (1, 1- diphenyl - 2 -picrylhydrazyl) and all chemicals used were of analytical grade and purchased from Sigma Company, Germany. The kits utilized for the biochemical analyses were purchased from Gamma Trade Company, Cairo Egypt. The basal pellet diet was obtained from the central animal house of the National Research Center, Dokki. Water was available ad libitum. Male rats weighing $180-230 \mathrm{~g}$ were obtained from the Agricultural Reached Center, Giza, Egypt.

\section{Methods}

\section{Manufacture of yoghurt:}

Milk containing $3 \%$ fat was used in the preparation of yoghurt and served as a control (C). Low fat buffalo's milk (1\% fat) was divided into 4 portions. The first portion was left without additive as a control (C1), dried Nabaq fruit was added to the other three portions at the rate of 2 and $4 \%$ (T1 and, T2). The fortified milk bases were homogenized and heated to $90{ }^{\circ} \mathrm{C}$ for $15 \mathrm{~min}$., then, cooled to $42 \pm 1$ ${ }^{\circ} \mathrm{C}$, inoculated with $2 \%$ of yoghurt starter cultures, filled in plastic cups and incubated at $42{ }^{\circ} \mathrm{C}$ until a uniform coagulation was obtained. The yoghurt samples from all treatments were stored at $6 \pm 1{ }^{\circ} \mathrm{C}$ and analyzed at fresh time (Kebary and Hussein, 1999).

\section{Chemical analysis:}

Total solids, fat, total protein (TP) contents, titratable acidity and dietary fiber of yoghurt samples were determined according to AOAC, (2007). The changes in $\mathrm{pH}$ in the yoghurt samples during 
Egyptian J. of Nutrition Vol. XXXVI No. 2 (2021)

storage were measured using a laboratory $\mathrm{pH}$ meter with glass electrode (HANNA, Instrument, Portugal). Carbohydrate, crude fiber ,ash , calcium, potassium and sodium contents were determined according to AOAC, (2007).while iron and zinc content were determined according to Page et al., (1992).

Rheological measurements:

The viscosity and released whey from yoghurt samples was measured according to the method of Aryana, (2003). The quantity of whey collected from every sample in graduated cylinder after $2 \mathrm{~h}$ of drainage at $20{ }^{\circ} \mathrm{C}$ was used as index of syneresis. Viscosity of nonfat yoghurt samples was determined using Rotational Viscometer Type Lab. Line Model 5437. Results expressed as Centipois (CPS).

\section{Sensory evaluation:}

The sensory properties of yoghurt samples were assessed by 10 panel members of the Dairy Sci., Dep., Fac. Agric., Zagazig, Univ. They evaluated $20 \mathrm{~g}$ portions of each yoghurt sample and used a quality rating score card for evaluation of color \& appearance ( 9 points), flavor (9 points), body\& texture (9 points), consistency ( 9 points) and overall acceptability as described by Nelson and Trout (1981).

Determination of ascorbic acid content:

Ascorbic acid was determined using 2, 6 dichlorophenol indophenol dye as described in AOAC (2007).

Determination of total phenolic content: 


\section{Atwaa E.H. , Hanan A. Radwan, Hanan S. Shalaby and Ghada M. El-Araby}

The concentration of total phenols in $B$. vulgaris leaves were measured by a UV spectrophotometer (Jenway-UV-VIS Spectrophotometer), based on a colorimetric oxidation/ reduction reaction, as described by Laličić-Petronijević et al. (2016).

\section{Determination of total flavonoids content:}

Total flavonoids content in the aqueous and ethanolic extracts was determined spectrophotometrically by the method of Zarina and Tan (2013).

\section{Radical scavenging activity (Scavenging DPPH):}

The antioxidant activity was evaluated by the DPPH (2, 2diphenyl-1-picrylhydrazyl) assay according to Brand Williams et al,(1995). The scavenging activity percentage (AOA \%) was determined according to Mensor et al,(2001) as follows:

$\mathrm{AOA}(\%)=1$ - Abs sample _ Abs blank / Abs control $\times 100$ (1)

\section{Experimental design of biological study:}

Forty-eight male adult Wistar rats weighing $180-230 \mathrm{~g}$ were collected from Agricultural Reached Center, Giza, Egypt. All animals kept under controlled conditions of light (12 h of light and $12 \mathrm{~h}$ of darkness) with the ambient temperature of $22 \pm 2^{\circ} \mathrm{C}$ and relative humidity of $40-60 \%$ and free access to water and food in the Animals' Room. All animals were allowed free access to standard 
Egyptian J. of Nutrition Vol. XXXVI No. 2 (2021)

diet. The normal diet composition was as follows: Casein (20\%), sucrose (50\%), Corn Starch (15\%), powdered cellulose (5\%), corn oil $(5 \%)$, mineral mix $(3.5 \%)$, vitamin mix (1\%), DL- Methionine $(0.3 \%)$, Choline bitartrate $(0.2 \%)$ according to AIN-93 guidelines (Reeves et al., 1993).

After acclimation on a basal diet for seven days Albino rats were classified into two main sections, where the first one $(n=8)$ received only the standard diet and served as the normal control group while the second one (hyperglycemia rats, $n=32$ ) was subjected to $60 \mathrm{mg} / \mathrm{Kg}$ BW Streptozotocin (STZ) intraperitoneally injection. After 24-48h, rats that showing fasting blood glucose more than $200 \mathrm{mg} \mathrm{dl}^{-1}$ was considered diabetic rats. Diabetic rats were divided into four groups ( $n=8$ each) .The first did not receive any treatment and served as the hyperglycemia positive control. The second, third and four ones received $10 \%$ low fat yoghurt, $10 \%$ low fat yoghurt fortified with $4 \%$ dried Nabaq fruit and Meglitinides (0.6 $\mathrm{mg} / \mathrm{kg}$ body mass) respectively.

The body weight of rats was measured at the beginning of experimental period and after 7 days intervals. At the end of the experiment and after an overnight fasting (10 hr), rats were killed, blood samples were collected and centrifuged at $3000 \mathrm{rpm}$ to obtain the blood serum which will store at $\left(-20^{\circ} \mathrm{C}\right)$ for biochemical analysis.

\section{Biochemical assays for lipids:}

Insulin was determined in human blood samples according to the method of (Thomas, et al., 2014). Blood glucose level was 


\section{Atwaa E.H. , Hanan A. Radwan, Hanan S. Shalaby and Ghada M. El-Araby}

determined according to the method of Clinical Methods (Trinder, 1969). Total cholesterol, was determined according to the method of Enzymatic Colorimeter, Deweerdt and Later (2009). Total lipids and triglycerides were determined according to the method of Devi and Sharma, (2004).

The LDL was calculated using Friedewald formula (Friedewald et al., 1972) as following:

LDL-cholesterol= Total cholesterol - (HDL-cholesterol) (Triglycerides/5)

Determination of liver function:

Alanine amino transferase (ALT), aspartate amino transferase (AST) enzymes were measured according to the methods described by Bergmeyer and Harder, (1986), Total bilirubin and total protein were determined according to the methods described by Tiertz, (1976), Henry, (1974), Moss, (1982), Gowanlock et al.,(1988) and Doumas, et al ., (1973) respectively.

\section{Determination of kidney functions:}

Urea, uric acid and creatinine were determined according to the method of While, et al., (1970), Henry, (1974), and Houot, (1985), respectively.

\section{Determination of antioxidant status:}


Egyptian J. of Nutrition Vol. XXXVI No. 2 (2021)

Total antioxidant capacity (TAC) and Malonaldhyde (MDA) were determined in according to the methods described by $\mathbf{H u}$, (1994), Aebi, (1974), and Jentzsch, et al., (1996), respectively.

\section{Histopathological examination:}

Pancreas, after removal from the rats were processed and stained with hematoxylin and eosin dyes then examined for histopathological changes under the light microscope (Banchroft et al., 1996).

\section{Statistical analysis:}

Finally, statistical data analysis will conducted using the oneway ANOVA test along with the Duncan test that was performed using the SPSS software (Chicago, IL, USA). All data were subjected to statistical analysis according to the procedure reported by Steel et al. (1997) and the statistical analysis system program (SAS, 1996).

\section{Results and Discussion}

\section{Chemical composition, minerals content and phytochemical proprieties of dried Nabaq fruit:}

Chemical composition, minerals content and phytochemical proprieties of dried Nabaq fruit is illustrated in Table (1). Moisture, protein, fat, ash and fiber contents of dried Nabaq fruit were (16.94, 4.72, $0.52,4.01$ and $3.12 \mathrm{~g} / 100 \mathrm{~g}$, respectively. This result agrees with Ahmed and Sati (2018) and Hashem and Abd El-Lahot (2021) who found that Moisture, protein, fat, ash and fiber contents of 


\section{Atwaa E.H. , Hanan A. Radwan, Hanan S. Shalaby and Ghada M. El-Araby}

Dried Nabaq fruit were $(17.65,4.58,0.59,3.89$ and $2.51 \mathrm{~g} / 100 \mathrm{~g}$, respectively. Also, data in Table (1) reveal that, the vitamin $C$, total phenolic and flavonoids content of dried Nabaq fruit were 19.22, 1986.8 and $192.4 \mathrm{mg} / 100 \mathrm{~g}$, respectively. While the radical scavenging activity (RSA \%) was 91.60. Similar results were obtained by Ahmed and Sati (2018) who found that ascorbic acid content was $8.64 \mathrm{mg} / 100 \mathrm{~g}$ in Nabaq fruit pulp. Also, Hashem and Abd El-Lahot (2021) found that the vitamin $C$, total phenolic and flavonoids content of dried Nabaq fruit were 18.95, 2200.10 and $180.01 \mathrm{mg} / 100 \mathrm{~g}$, respectively.

The same Table (1) shows the minerals content of Dried Nabaq fruit. The results showed that $\mathrm{Ca}, \mathrm{K}, \mathrm{Na} \mathrm{Zn}, \mathrm{Fe}$ and $\mathrm{Zn}$ contents of Dried Nabaq fruit were (134.20, 810.34, 75.80, 12.18 . and 15.42 (mg/100 g dry weight basis) respectively. These results are in agreement with the data obtained by Hashem and Abd EILahot (2021) found that Dried Nabaq fruit containing Ca (146.53 $\mathrm{mg} / 100 \mathrm{~g}), \mathrm{K}(790.75 \mathrm{mg} / 100 \mathrm{~g}), \mathrm{Na}(80.33 \mathrm{mg} / 100 \mathrm{~g})$, Fe (10.20 $\mathrm{mg} / 100 \mathrm{~g})$ and $\mathrm{Zn}(14.91 \mathrm{mg} / 100 \mathrm{~g})$ also, El Maaiden et al. (2020) who exhibited that $\mathrm{Ca}, \mathrm{K}$, and $\mathrm{Na}$ of $\mathrm{Nabaq}$ fruit were78.37 to 74.80 , 203.20 to 179.65 , and 33.70 to $22.77 \mathrm{mg} / 100 \mathrm{~g}$, respectively .

\section{Chemical composition of low fat yoghurt supplemented with dried Nabaq fruit :}

Results illustrated in Table (2) show that the highest total solids (TS) were observed in full fat yoghurt ( $3 \%$ fat) compared with 
Egyptian J. of Nutrition Vol. XXXVI No. 2 (2021)

reduced fat yoghurt treatments. Supplementation low fat yoghurt with dried Nabaq fruit increased gradually the TS contents with increase the supplementation ratios. On the other said the lowest protein content was observed in control full fat yoghurt $(C)$ compared to low fat treatments. Supplementation low fat yoghurt with dried Nabaq fruit slightly increased protein content with increase the supplementation ratios. Regarding fat content, addition of dried Nabaq fruit to reduced fat milk did not affect the fat content of reduced fat yoghurt treatments. With respect to fiber content supplementation low fat yoghurt with dried Nabaq fruit increased fiber content and these increments were proportional to the supplementation ratio. These results are the line with those reported by Atwaa et al,(2020) who found that supplementation of low fat probiotic yoghurt with mango pulp fiber waste increased TS, protein, ash and fiber contents of low fat yoghurt samples.

Acidity, pH, whey syneresis, viscosity, total phenolic content and radical scavenging of low fat yoghurt supplemented with dried Nabaq fruit :

Data presented in Table (3) reveal that control low fat yoghurt contained the highest acidity, compared with full fat yoghurt; supplementation of low fat yoghurt with dried Nabaq fruit decreased the acidity. The $\mathrm{pH}$ values of the dried Nabaq fruit fortified yoghurt samples took an opposite direction to the acidity values.

The supplementation of low fat yoghurt with dried Nabaq fruit significantly decreased whey separation, compared with control low fat yoghurt .Control low fat yoghurt had the highest whey separation 


\section{Atwaa E.H. , Hanan A. Radwan, Hanan S. Shalaby and Ghada M. El-Araby}

compared to other treatments. Results in Table (3) also show that control low fat yoghurt (C1) was significantly lower viscosity, compared with full fat and supplemented low fat yoghurt. Supplementation of low fat yoghurt with dried Nabaq fruit increased the viscosity of reduced fat yoghurt. Also, data presented in Table 3 show that TPC (mg $/ 100 \mathrm{~g}$ ) and RSA \% of reduced fat yoghurt enriched with dried Nabaq fruit increased by increasing the supplementation ratio.

The current data align with Dabija et al, (2018), who found that addition of inulin, pea, oat and wheat to yoghurt reduced its acidity, whey syneresis and increased viscosity, TPC and RSA\% than control yoghurt. Also, Atwaa et al, (2020) found that addition of mango pulp fiber waste powder to low fat yoghurt reduced its acidity, whey syneresis and increased viscosity, TPC and RSA\% than control yoghurt.

\section{Organoleptic characteristics of low fat yoghurt supplemented with dried Nabaq fruit:}

From data presented in Table (4), it can be seen that, the lowest organoleptic characteristics scores was observed in control low fat yoghurt (C1), while adding dried Nabaq fruit to low fat yoghurt enhanced its organoleptic properties and this enhancement was proportional to the supplementation ratio, low fat yoghurt enriched with $4 \%$ dried Nabaq fruit was similar to the control full fat yoghurt (3\% fat). Similar results were obtained by Al-hamdani et al, 
Egyptian J. of Nutrition Vol. XXXVI No. 2 (2021)

(2015) and Atwaa et al, (2020) who found that supplementation of low fat yoghurt with 2 and $4 \%$ of lupine or $3 \%$ mango pulp fiber waste powder showed the positive effect on sensory scores.

\section{Effect of low fat yoghurt supplemented with dried Nabaq fruit on} blood glucose and insulin of rate groups:

Data presented in Table 5, shows that in STZ-induced diabetic rats the blood glucose levels were significantly increased $(p<0.001)$, while insulin levels of STZ-induced diabetic rats were decreased in comparison to their normal levels. Administration low fat yoghurt fortified with $4 \%$ dried Nabaq fruit in diabetic treated groups lead to significant decrease $(p<0.001)$ in serum glucose level as compared with untreated STZ-induced diabetic rats this may be due to ability of Nabaq fruit on decreasing glycosylated haemoglobin (HbA1c), which further damages the blood vessels through oxidative stress by preventing oxidative damage caused by glycation reaction in diabetic conditions as a result of decreased blood glucose level and increased insulin secretion(Bandawane et al.,2020) .

Also, a significant decrease $(p<0.05)$ was observed in serum glucose level in group 5 treated with Meglitinides than the other group. In line with our results, Michel et al, (2011), Avize et al.(2010) and Bencheikh et al,(2021) who found that diabetic rats treated with fruit extract of Zizyphus spina-christi( Nabaq ) showed increasing in the blood insulin levels and decreasing in the blood sugar levels compared to the untreated diabetic rats group. 


\section{Atwaa E.H. , Hanan A. Radwan, Hanan S. Shalaby and Ghada M. El-Araby}

\section{Effect of low fat yoghurt supplemented with dried Nabaq fruit on the serum lipid profile of diabetic rate groups:}

From Table 6 , it can be noticed that, group 5 treated with Meglitinides had the lowest total cholesterol $(75.50 \mathrm{mg} / \mathrm{dl})$ compared to another groups, while rat's administration of diet supplemented with low fat yoghurt containing dried Nabaq fruit recorded significant decrease in total cholesterol $(79.13 \mathrm{mg} / \mathrm{dl})$ compared to positive and negative control .

Concerning triacylglyceride and LDL rat $(+v e)$ control group had the highest content of triacylglyceride and LDL (154.20 and $114.50 \mathrm{mg} / \mathrm{dl}$, respectively ) compared to all groups, while rat's treated with Meglitinides and low fat yoghurt containing Dried Nabaq fruit had the lowest recorded significant decrease in triacylglyceride and LDL values compared to positive and negative control. As for HDL content, (+ve) control group had the lowest HDL content (31.40 $\mathrm{mg} / \mathrm{dl}$ ) compared to others group, while rat's administration of diet supplemented with low fat yoghurt containing dried Nabaq fruit recorded significant increase in HDL content compared to positive and negative control .

There was significant increase $(\mathrm{P}<0.05)$ in the levels of serum cholesterol, triacylglyceride and LDL-C and a decrease in level of HDL-C in the positive control when compared to normal fed rats. Elevated level of blood cholesterol especially LDL-c is a known major risk factor for CHD whereas HDL-c is cardio protective (Pankaj et al., 
Egyptian J. of Nutrition Vol. XXXVI No. 2 (2021)

2010). Treatment with low fat yoghurt containing dried Nabaq fruit significantly decreased the levels of total cholesterol, triglycerides and LDL-c as compare to the positive control. Positive control causes the oxidative stress which finally increases production of reactive oxygen species.

An increasing scientific literature provides ample direct. Or indirect evidence that overproduction of ROS can induce cellular damage via oxidation of critical cellular components such as membrane lipids, proteins, and DNA. Since the result of the study indicated that $B$. vulgaris leaves extract has beneficial effect on lipid profile we have investigated its mechanism of action this may be due to phenolic compounds as natural antioxidants present in dried Nabaq fruit (Ahmed and Sati (2018) and Hashem and Abd ElLahot (2021). Similar results were obtained by Khader et al., (2017) and Bencheikh et al, (2021), who indicated that the ethanol extraction of Nabaq fruit decreased $(P<0.05)$ in the levels of serum cholesterol, triacylglyceride and LDL-c and increased in level of HDL$\mathrm{c}$ in diabetic rats.

Effect of low fat yoghurt supplemented with dried Nabaq fruit on total antioxidant capacity (TAC) and malondialdehyde (MDA) of diabetic rate:

Results of antioxidative indices (TAC and MDA) are summarized in Table (7). As for total antioxidant capacity (TAC) and malondialdehyde (MDA), there were significant differences among the groups. Mean value of TAC was $740 \pm 14 \mu \mathrm{mol} / \mathrm{L}$ for negative control, then decreased significantly compared to positive control 


\section{Atwaa E.H. , Hanan A. Radwan, Hanan S. Shalaby and Ghada M. El-Araby}

$(510 \pm 0.21 \mu \mathrm{mol} / \mathrm{L})$ by enhancing food in the low fat yoghurt containing dried Nabaq fruit. There is a significant increase in diabetic rat groups treated with low fat yoghurt and low fat yoghurt containing dried Nabaq fruit with $615 \pm 58$ and $720 \pm 46 \mu \mathrm{mol} / \mathrm{L}$, respectively. Group 5 treated with Meglitinides had the highest TAC value with $770 \pm 35$.

Concerning MDA, it can noticed that positive control was $4.5 \pm 0.8$ which considered the highest mean value of MDA compared to negative control which recorded the lowest value $(1.33 \pm 0.4)$. There is a significant decrease in diabetic rat groups treated with low fat yoghurt and low fat yoghurt containing dried Nabaq fruit with $3.1 \pm 0.2$ and $2.3 \pm 0.4 \mu \mathrm{mol} / \mathrm{L}$, respectively. Group 5 treated with Meglitinides had the lowest MDA value with $1.75 \pm 0.6$ compared to positive control.

Malondialdehyde has a very devastating process altering the structure and function of cell membranes (Nair and Nair, 2015). Koc (2003), demonstrated that the formation and increase of MDA level can lead to oxidative mechanisms, high cytotoxicity and inhibitory actions. MDA acts as a tumor promoter and co-carcinogenic agent. On the other side, the increase of total antioxidant capacity (TAC) is evidence of improved antioxidative status according to Joshi et al. (2015). Similar results were obtained by Al-Ghamdi et al,(2019) who indicated that the ethanol extraction of Nabaq fruit decreased in the levels of MDA and increased in levels of TAC in diabetic rats. 
Egyptian J. of Nutrition Vol. XXXVI No. 2 (2021)

Effect of low fat yoghurt supplemented with dried Nabaq fruit on AST, ALT and ALP parameters in diabetic rate:

Data illustrated in Table (8) showed that the untreated group (positive control) showed significant increase in AST, ALT and ALP at $(p<0.05)$ in comparing with normal control group. On the other hand the treated group showed significant decrease in AST, ALT and ALP comparing with positive control group.

AST, ALT and ALP parameters of different treated rat groups were reduced respectively as follows (undiabetic rat (negative control), rat group treated with Meglitinides, rat group treated low fat yoghurt supplemented with dried Nabaq fruit and rat group treated with low fat yoghurt) in comparison to untreated group (positive control).

This decrease in the values of aminotransferase enzymes and the restoration of some vital functions by the hepatocytes can be attributed to the high content of Nabaq fruit of antioxidants, which work to preserve the plasma membrane in hepatocytes and protect it from rupture and the exit of the cytosol loaded with these enzymes.

( Bencheikh et al ,2021 ) These results were collaborated by Abubakar et al.(2018), who found that Nabaq fruit supplementation effectiveness in decrease in AST ,ALT and ALP comparing with positive control group.

Effect of low fat yoghurt supplemented with dried Nabaq fruit on creatinin, uric acid and urea parameters in in diabetic rate:

Data presented in table (9) showed that the untreated group (positive control) showed significant increase in creatinin, uric acid 


\section{Atwaa E.H. , Hanan A. Radwan, Hanan S. Shalaby and Ghada M. El-Araby}

and urea at $(p<0.05)$ in comparing with normal control group. On the other hand the treated group showed significant decrease in creatinin, Uric acid and Urea comparing with positive control group. Creatinin, Uric acid and Urea of different treated rat groups were reduced respectively as follows (undiabetic rat (negative control), rat group treated with Meglitinides , rat group treated with low fat yoghurt containing dried Nabaq fruit and rat group treated with 2 low fat yoghurt) in comparison to untreated group (positive control). These results were collaborated by Khader et al.,(2017) and Al-Ghamdi et al, (2019) who found that Nabaq fruit supplementation effectiveness in decrease in uric acid, and urea comparing with positive control group.

\section{Light microscopic histological study:} Group 1 (Control group = G1):

Light microscopic examination of stained sections with $H$ \& $E$ from the pancreas of $\mathrm{G} 1$ revealed multiple normal pancreatic lobules and thin CT septa. The exocrine parenchyma had numerous pancreatic acini of pyramidal acinar cells, while the islets of Langerhan's appeared as large pale oval areas with a well-defined contour between the exocrine acini. They consisted of multiple small pale $\beta$ cells and few large acidophilic rounded alpha cells around small blood capillaries.

\section{Group II (Streptozotocin (STZ) treated diabetic rats):}


Egyptian J. of Nutrition Vol. XXXVI No. 2 (2021)

Light microscopic examination of stained sections with $\mathrm{H}$ \& $\mathrm{E}$ from the pancreas of $\mathrm{G} 2$ rats showed distorted pancreatic lobules and acini separated by edema and contained dilated ducts. The acinar cells had few vacuoles and most of the islets of Langerhan's were reduced in number. (Figure 2).

\section{Group III: (STZ-treated diabetic rats \& $20 \%$ low fat yoghurt):}

Light microscopic examination of stained sections with $\mathrm{H}$ \& $\mathrm{E}$ from the pancreas of G3 revealed multiple normal pancreatic lobules and thin CT septa. The exocrine parenchyma had numerous pancreatic acini of pyramidal acinar cells, while the islets of Langerhan's appeared as a well-defined large pale areas between the exocrine acini. (Figure 3).

\section{Group IV (STZ-treated diabetic rats \& 20\% low fat yoghurt containing dried Nabaq fruit)}

Light microscopic examination of stained sections with $\mathrm{H}$ \& $\mathrm{E}$ from the pancreas, liver and kidney of G4 revealed multiple normal pancreatic lobules of numerous exocrine pancreatic acini, while the islets of Langerhan's appeared as a well-defined large pale oval areas around small blood capillaries and between the exocrine acini. (Figure 4).

\section{Group V: (STZ-treated diabetic rats \& Meglitinides-treated diabetic rats):}

Light microscopic examination of stained sections with $\mathrm{H}$ \& $\mathrm{E}$ from the pancreas of G5 rats showed distorted pancreatic lobules, acini, and contained dilated ducts. The acinar cells had few vacuoles 


\section{Atwaa E.H. , Hanan A. Radwan, Hanan S. Shalaby and Ghada M. El-Araby}

and most of the islets of Langerhan's were reduced in number. (Figure 5).

\section{Conclusion}

Nabaq (Zizyphus spina-christi L) fruit showed strong antioxidant capacity and high content of phenolic component. Therefore, dried Nabaq (Zizyphus spina-christi $\mathrm{L}$ ) fruit could be used as natural additives in manufacture of low fat yoghurt to improve its physicochemical, rheological and sensory properties. Also, the observed blood sugar reducing action of the Nabaq (Zizyphus spinachristi L) fruit powder indicates the hypoglycemia activity.

Table (1):Chemical composition, minerals content and phytochemical proprieties of dried Nabaq fruit

\begin{tabular}{l|c}
\hline \multicolumn{2}{c}{ Chemical composition } \\
\hline Moisture (\%) & $16.94 \pm 0.45$ \\
\hline Total protein (\%) & $4.72 \pm 0.18$ \\
\hline Fat (\%) & $0.52 \pm 0.03$ \\
\hline Ash (\%) & $4.01 \pm 0.12$ \\
\hline Fiber (\%) Minerals (mg/100 g dry weight basis) \\
\hline \multicolumn{2}{|c}{$3.12 \pm 0.25$} \\
\hline Calcium (Ca ) & $134.20 \pm 4.3$ \\
\hline Potassium (K) & $810.34 \pm 6.8$ \\
\hline Sodium (Na) & $75.80 \pm 2.7$ \\
\hline Iron (Fe) & $12.18 \pm 1.02$ \\
\hline
\end{tabular}


Egyptian J. of Nutrition Vol. XXXVI No. 2 (2021)

\begin{tabular}{l|c}
\hline Zinc $(\mathrm{Zn})$ & $15.42 \pm 1.18$ \\
\hline \multicolumn{2}{|c}{ Phytochemicals } \\
\hline Vitamin C $(\mathrm{mg} / 100 \mathrm{~g})$ & $19.22 \pm 0.40$ \\
\hline Total phenolic content $(\mathrm{mg} / \mathrm{g})$ & $1986,8 \pm 8.6$ \\
\hline Total flavonoids $(\mathrm{mg} / 100 \mathrm{~g})$ & $192.4 \pm 4.3$ \\
\hline Radical scavenging activity $(\%)$ & $91.60 \pm 3.6$ \\
\hline
\end{tabular}

Table 2:Effect of supplementation low fat yoghurt with dried Nabaq fruit on chemical composition

\begin{tabular}{l|c|c|c|c}
\hline \multirow{2}{*}{ Components (\%) } & \multicolumn{4}{|c}{ Treatments } \\
\cline { 2 - 5 } Total Solids & $\mathrm{C}$ & $\mathrm{C}_{1}$ & $\mathrm{~T}_{1}$ & $\mathrm{~T}_{2}$ \\
\hline Fat & $12.14 \pm 0.30^{\mathrm{a}}$ & $10.24 \pm 0.42^{\mathrm{d}}$ & $11.02 \pm 0.38^{\mathrm{b}}$ & $11.86 \pm 0.32^{\mathrm{c}}$ \\
\hline Protein & $3.10 \pm 0.14^{\mathrm{a}}$ & $1.12 \pm 0.07^{\mathrm{b}}$ & $1.14 \pm 0.05^{\mathrm{b}}$ & $1.18 \pm 0.04^{\mathrm{b}}$ \\
\hline Fiber & $3.60 \pm 0.22^{\mathrm{b}}$ & $3.94 \pm 0.16^{\mathrm{a}}$ & $3.98 \pm 0.10^{\mathrm{a}}$ & $4.02 \pm 0.08^{\mathrm{a}}$ \\
\hline
\end{tabular}

\footnotetext{
* Values (means \pm SD) with different superscript letters are statistically significantly different $(P \leq 0.05)$.

C: Control full fat yoghurt ( $3 \%$ fat) $\quad$ C ${ }_{1}$ : Control low fat yoghurt $(1 \%$ fat).

$\mathrm{T}_{1}$ : Low fat yoghurt containing $2 \%$ dried Nabaq fruit
}

173 


\section{Atwaa E.H. , Hanan A. Radwan, Hanan S. Shalaby and Ghada M. El-Araby}

$\mathrm{T}_{2}$ : Low fat yoghurt containing $4 \%$ dried Nabaq fruit

Table 3:Effect of supplementation low fat yoghurt with dried Nabaq fruit on acidity, $\mathrm{pH}$, whey syneresis, viscosity, total phenolic content and radical scavenging

\begin{tabular}{c|c|c|c|c}
\hline \multirow{2}{*}{ Parameters } & \multicolumn{4}{|c}{ Treatments } \\
\cline { 2 - 5 } Acidity \% & $0.80 \pm 0.03^{\mathrm{b}}$ & $0.88 \pm 0.04^{\mathrm{a}}$ & $0.83 \pm 0.05^{\mathrm{ab}}$ & $0.78 \pm 0.03^{\mathrm{c}}$ \\
\hline $\mathrm{pH}$ & $4.68 \pm 0.05^{\mathrm{b}}$ & $4.28 \pm 0.06^{\mathrm{d}}$ & $4.60 \pm 0.03 \mathrm{c}$ & $4.72 \pm 0.05^{\mathrm{a}}$ \\
\hline $\begin{array}{c}\text { syneresis } \\
(\mathrm{ml} / 100 \mathrm{gm})\end{array}$ & $21.00 \pm 1.14^{\mathrm{d}}$ & $30.00 \pm 1.32^{\mathrm{a}}$ & $28.00 \pm 1.20 \mathrm{~b}$ & $25.00 \pm 1.14^{\mathrm{c}}$ \\
\hline $\begin{array}{c}\text { Viscosity } \\
(\text { C. P.S. })\end{array}$ & $5490 \pm 8.2^{\mathrm{a}}$ & $4280 \pm 10.5^{\mathrm{d}}$ & $4320 \pm 9.20 \mathrm{c}$ & $4520 \pm 10.0^{\mathrm{b}}$ \\
\hline $\begin{array}{c}\text { TPC } \\
(\mathrm{mg} / 100 \mathrm{~g})\end{array}$ & $52.70 \pm 2.4^{\mathrm{c}}$ & $44.50 \pm 2.46^{\mathrm{d}}$ & $62.80 \pm 1.77 \mathrm{~b}$ & $80.30 \pm 1.65^{\mathrm{a}}$ \\
\hline
\end{tabular}


Egyptian J. of Nutrition Vol. XXXVI No. 2 (2021)

\begin{tabular}{|c|c|c|c|c|}
\hline RSA \% & $22.14 \pm 1.0^{c}$ & $18.86 \pm 1.22^{d}$ & $30.44 \pm 1.12 b$ & $38.70 \pm 1.34^{\mathrm{a}}$ \\
\hline \multicolumn{5}{|c|}{$\begin{array}{l}\text { *Values (means } \pm S D) \text { with different superscript letters are statistically significantly } \\
\text { different }(P \leq 0.05) \text {. }\end{array}$} \\
\hline \multicolumn{2}{|c|}{$\begin{array}{l}\text { C: Control full fat yoghurt ( } 3 \% \text { fat }) \\
\text { fat). }\end{array}$} & & \multicolumn{2}{|c|}{$\mathrm{C}_{1}$ : Control low fat yoghurt $(1 \%$} \\
\hline \multicolumn{5}{|c|}{$\mathrm{T}_{1}$ : Low fat yoghurt containing $2 \%$ dried Nabaq fruit } \\
\hline \multicolumn{5}{|c|}{$\mathrm{T}_{2}$ : Low fat yoghurt containing $4 \%$ dried Nabaq fruit } \\
\hline
\end{tabular}

Table (4):Organoleptic characteristics of low fat yoghurt supplemented with dried Nabaq fruit

\begin{tabular}{l|c|c|c|c}
\hline \multirow{2}{*}{ Properties } & \multicolumn{4}{|c}{ Treatments } \\
\cline { 2 - 5 } Appearance & $9.40 \pm 0.20^{\mathrm{a}}$ & $7.60 \pm 0.24^{\mathrm{d}}$ & $7.70 \pm 0.22^{\mathrm{c}}$ & $7.90 \pm 0.14^{\mathrm{b}}$ \\
\hline Flavour & $8.80 \pm 0.33^{\mathrm{a}}$ & $7.50 \pm 0.48^{\mathrm{d}}$ & $7.90 \pm 0.32^{\mathrm{c}}$ & $8.20 \pm 0.24^{\mathrm{b}}$ \\
\hline Texture & $8.90 \pm 0.28^{\mathrm{a}}$ & $6.50 \pm 0.36^{\mathrm{d}}$ & $6.90 \pm 0.30^{\mathrm{c}}$ & $7.40 \pm 0.26^{\mathrm{b}}$ \\
\hline Consistency & $8.50 \pm 0.20^{\mathrm{a}}$ & $6.20 \pm 0.33^{\mathrm{e}}$ & $6.70 \pm 0.28^{\mathrm{d}}$ & $7.50 \pm 0.20^{\mathrm{c}}$ \\
\hline $\begin{array}{l}\text { Overall } \\
\text { acceptability }\end{array}$ & $8.90 \pm 0.28^{\mathrm{a}}$ & $6.40 \pm 0.48^{\mathrm{d}}$ & $7.20 \pm 0.33^{\mathrm{c}}$ & $8.10 \pm 0.22^{\mathrm{b}}$ \\
\hline
\end{tabular}

* Values (means $\pm S D$ ) with different superscript letters are statistically significantly different $(P \leq 0.05)$. 


\section{Atwaa E.H. , Hanan A. Radwan, Hanan S. Shalaby and Ghada M. El-Araby}

C: Control full fat yoghurt ( $3 \%$ fat)

C $_{1}$ : Control low fat yoghurt $(1 \%$ fat).

$\mathrm{T}_{1}$ : Low fat yoghurt containing $2 \%$ dried Nabaq fruit

$\mathrm{T}_{2}$ : Low fat yoghurt containing $4 \%$ dried Nabaq fruit

Table 5:Effect of low fat yoghurt supplemented with dried Nabaq fruit on blood glucose and insulin of rate groups

\begin{tabular}{ll|c|c}
\hline \multirow{2}{*}{ Groups } & \multicolumn{2}{|c}{ Parameters } \\
\cline { 2 - 4 } & $\begin{array}{c}\text { Blood glucose } \\
\text { concentration }(\mathrm{mg} / \mathrm{dL})\end{array}$ & Insulin $(\mu \mathrm{U} / \mathrm{ml})$ \\
\hline$-\quad$ Group (1): & $94.30 \pm 4.80^{\mathrm{c}}$ & $17.20 \pm 0.12^{\mathrm{a}}$ \\
\hline$-\quad$ Group (2): & $260.70 \pm 8.66^{\mathrm{a}}$ & $7.40 \pm 0.40^{\mathrm{e}}$ \\
\hline$-\quad$ Group (3): & $102.90 \pm 5.80^{\mathrm{b}}$ & $10.60 \pm 0.32^{\mathrm{d}}$ \\
\hline$-\quad$ Group (4): & $95.80 \pm 5.10^{\mathrm{c}}$ & $13.40 \pm 0.22^{\mathrm{c}}$ \\
\hline- & Group (5): & $88.20 \pm 8.30^{\mathrm{d}}$ & $14.70 \pm 0.30^{\mathrm{b}}$ \\
\hline
\end{tabular}

Mean values of six rat's \pm SD. A, b, c.... of the small letters in the same column are significantly different at $(p \leq 0.05)$.. 
Egyptian J. of Nutrition Vol. XXXVI No. 2 (2021)

Group (1): non-treated non-diabetic rats (negative control).

Group (2) :non-treated diabetic rats (positive control).

Group (3): diabetic rats treated with $10 \%$ low fat yoghurt.

Group (4): diabetic rats treated with $10 \%$ low fat yoghurt fortified with $4 \%$ dried Nabaq fruit.

Group (5): diabetic rats treated with Meglitinides.

Table 6:Effect of low fat yoghurt supplemented with dried Nabaq fruit on lipid profile of diabetic rate groups

\begin{tabular}{ll|c|c|c|c}
\hline & Parameter & $\begin{array}{c}\text { Total cholesterol } \\
(\mathrm{TC})(\mathrm{mg} / \mathrm{dl})\end{array}$ & $\begin{array}{c}\text { Triglycerides } \\
(\mathrm{TG})(\mathrm{mg} / \mathrm{dl})\end{array}$ & $\begin{array}{c}\text { HDL-c } \\
(\mathrm{mg} / \mathrm{dl})\end{array}$ & $\begin{array}{c}\text { LDLc } \\
(\mathrm{mg} / \mathrm{dl})\end{array}$ \\
\hline- & Group (1): & $97.30 \pm 3.22^{\mathrm{b}}$ & $133.40 \pm 8.40^{\mathrm{b}}$ & $45.00 \pm 2.34^{\mathrm{a}}$ & $25.62 \pm 1.70^{\mathrm{c}}$ \\
\hline$-\quad$ & Group (2): & $114.50 \pm 6.54^{\mathrm{a}}$ & $154.20 \pm 7.20^{\mathrm{a}}$ & $31.40 \pm 2.50^{\mathrm{d}}$ & $52.26 \pm 4.52^{\mathrm{a}}$ \\
\hline$-\quad$ & Group (3): & $84.44 \pm 2.35^{\mathrm{c}}$ & $101.12 \pm 5.40^{\mathrm{c}}$ & $35.64 \pm 2.24^{\mathrm{c}}$ & $28.58 \pm 2.34^{\mathrm{b}}$ \\
\hline$-\quad$ & Group (4): & $79.13 \pm 2.52^{\mathrm{d}}$ & $95.04 \pm 4.60^{\mathrm{d}}$ & $39.50 \pm 2.64^{\mathrm{b}}$ & $20.62 \pm 3.24^{\mathrm{d}}$ \\
\hline- & Group (5): & $75.50 \pm 2.38^{\mathrm{e}}$ & $89.60 \pm 3.20^{\mathrm{e}}$ & $43.22 \pm 2.40^{\mathrm{a}}$ & $14.36 \pm 1.40^{\mathrm{e}}$ \\
\hline
\end{tabular}

Mean values of six rat's \pm SD. A, b, c....of the small letters in the same column are significantly different at $(p \leq 0.05)$.

Group (1): non-treated non-diabetic rats (negative control). 


\section{Atwaa E.H. , Hanan A. Radwan, Hanan S. Shalaby and Ghada M. El-Araby}

Group (2) :non-treated diabetic rats (positive control).

Group (3): diabetic rats treated with $10 \%$ low fat yoghurt.

Group (4): diabetic rats treated with $10 \%$ low fat yoghurt fortified with $4 \%$ dried Nabaq fruit.

Group (5): diabetic rats treated with Meglitinides.

Table 7:Effect of low fat yoghurt supplemented with dried Nabaq fruit on total antioxidant capacity (TAC) and malondialdehyde (MDA) of diabetic rats

\begin{tabular}{c|c|c}
\hline Proups & $\begin{array}{c}\text { Malondialdehyde } \\
(\mathrm{MDA})(\mu \mathrm{mol} / \mathrm{L})\end{array}$ & $\begin{array}{c}\text { Total antioxidant } \\
(\mathrm{FRAP})(\mu \mathrm{mol} / \mathrm{L})\end{array}$ \\
\hline Group (1): & $1.33 \pm 0.4^{\mathrm{e}}$ & $740 \pm 24^{\mathrm{b}}$ \\
\hline Group (2): & $4.5 \pm 0.8^{\mathrm{a}}$ & $510 \pm 21^{\mathrm{d}}$ \\
\hline Group (3): & $3.1 \pm 0.2^{\mathrm{b}}$ & $615 \pm 58^{\mathrm{c}}$ \\
\hline Group (4): & $2.3 \pm 0.4^{\mathrm{c}}$ & $720 \pm 46 \mathrm{~b}^{\mathrm{c}}$ \\
\hline Group (5): & $1.75 \pm 0.6^{\mathrm{d}}$ & $770 \pm 35^{\mathrm{a}}$ \\
\hline
\end{tabular}


Egyptian J. of Nutrition Vol. XXXVI No. 2 (2021)

Mean values of six rat's \pm SD. $A, b, c . .$. of the small letters in the same column are significantly different at $(p \leq 0.05)$.

Group (1): non-treated non-diabetic rats (negative control).

Group (2) :non-treated diabetic rats (positive control).

Group (3): diabetic rats treated with $10 \%$ low fat yoghurt.

Group (4): diabetic rats treated with $10 \%$ low fat yoghurt fortified with $4 \%$ dried Nabaq fruit.

Group (5): diabetic rats treated with Meglitinides.

Table 8:Effect of low fat yoghurt supplemented with dried Nabaq fruit on AST, ALT and ALP parameters in diabetic rate

\begin{tabular}{c|c|c|c}
\hline Groups & $\begin{array}{c}\text { Aspartate } \\
\text { aminotransferase } \\
(\text { AST U/L })\end{array}$ & $\begin{array}{c}\text { Alanine } \\
\text { aminotransferase } \\
(\text { ALT U/L ) }\end{array}$ & $\begin{array}{c}\text { Alkaline } \\
\text { phosphatase } \\
(\text { ALP U/L })\end{array}$ \\
\hline Group (1): & $61.30 \pm 4.16^{\mathrm{d}}$ & $22.02 \pm 1.248^{\mathrm{e}}$ & $141.80 \pm 6.04^{\mathrm{d}}$ \\
\hline Group (2): & $86.06 \pm 3.40^{\mathrm{a}}$ & $36.60 \pm 3.12^{\mathrm{a}}$ & $169.54 \pm 5.24^{\mathrm{a}}$ \\
\hline Group (3): & $80.88 \pm 2.12^{\mathrm{b}}$ & $34.54 \pm 1.48^{\mathrm{b}}$ & $161.30 \pm 5.70^{\mathrm{b}}$ \\
\hline Group (4): & $75.04 \pm 3.84^{\mathrm{c}}$ & $32.62 \pm 3.28^{\mathrm{c}}$ & $155.56 \pm 6.02^{\mathrm{c}}$ \\
\hline Group (5): & $73.50 \pm 3.90^{\mathrm{c}}$ & $30.70 \pm 2.15^{\mathrm{d}}$ & $152.26 \pm 6.25^{\mathrm{c}}$ \\
\hline
\end{tabular}




\section{Atwaa E.H. , Hanan A. Radwan, Hanan S. Shalaby and Ghada M. El-Araby}

Mean values of six rat's $\pm S D$. $A, b, c \ldots$. of the small letters in the same column are significantly different at $(p \leq 0.05)$.

Group (1): non-treated non-diabetic rats (negative control).

Group (2) :non-treated diabetic rats (positive control).

Group (3): diabetic rats treated with $10 \%$ low fat yoghurt.

Group (4): diabetic rats treated with $10 \%$ low fat yoghurt fortified with $4 \%$ dried Nabaq fruit.

Group (5): diabetic rats treated with Meglitinides

Table 9:Effect of low fat yoghurt supplemented with dried Nabaq fruit on creatinin, uric acid and urea parameters in diabetic rate

\begin{tabular}{|c|c|c|c|}
\hline Parameter & Creatinin Mg\dl & Uric acid Mg\dl & Urea Mg\dl \\
\hline Groups & Mean $\pm S D$ & Mean $\pm S D$ & Mean $\pm S D$ \\
\hline Group (1): & $0.86 \pm 0.06^{d}$ & $2.38 \pm 0.16^{d}$ & $26.52 \pm 1.05^{d}$ \\
\hline Group (2): & $1.75 \pm 0.14^{\mathrm{a}}$ & $4.72 \pm 0.14^{a}$ & $44.08 \pm 3.22^{a}$ \\
\hline Group (3): & $1.24 \pm 0.10^{b}$ & $3.50 \pm 0.28^{b}$ & $32.04 \pm 2.12^{b}$ \\
\hline Group (4): & $1.10 \pm 0.08^{\mathrm{bc}}$ & $3.22 \pm 0.34^{\mathrm{bc}}$ & $29.40 \pm 2.18^{c}$ \\
\hline Group (5): & $0.96 \pm 0.04^{c}$ & $3.04 \pm 0.26^{c}$ & $27.10 \pm 2.24^{d}$ \\
\hline
\end{tabular}


Egyptian J. of Nutrition Vol. XXXVI No. 2 (2021)

Mean values of six rat's $\pm S D$. A, b, c....of the small letters in the same column are significantly different at $(p \leq 0.05)$.

Group (1): non-treated non-diabetic rats (negative control).

Group (2) :non-treated diabetic rats (positive control).

Group (3): diabetic rats treated with $10 \%$ low fat yoghurt.

Group (4): diabetic rats treated with $10 \%$ low fat yoghurt fortified with $4 \%$ dried Nabaq fruit.

Group (5): diabetic rats treated with Meglitinides

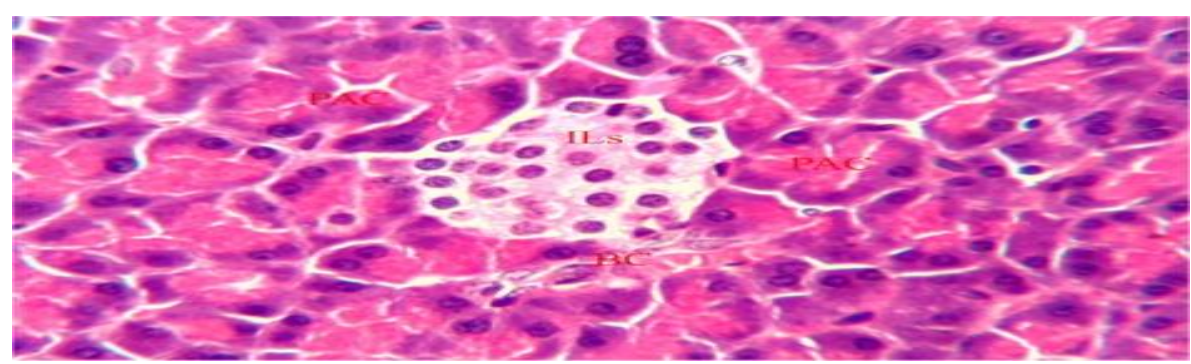

Figure 1: Photomicrographs of sections from the pancreatic tissues of $\mathrm{G} 1$ adult male albino rats. $\mathrm{H} \& \mathrm{E} \times 640$. 
Atwaa E.H. , Hanan A. Radwan, Hanan S. Shalaby and Ghada M. El-Araby

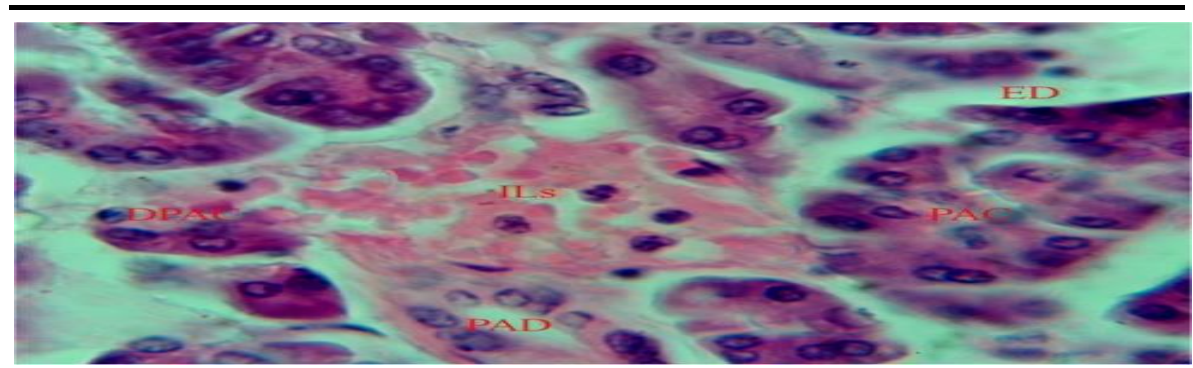

Figure 2: Photomicrographs of sections from the pancreatic of $\mathrm{G} 2$ adult male albino rats. $\mathrm{H} \& \mathrm{E} \times 640$.

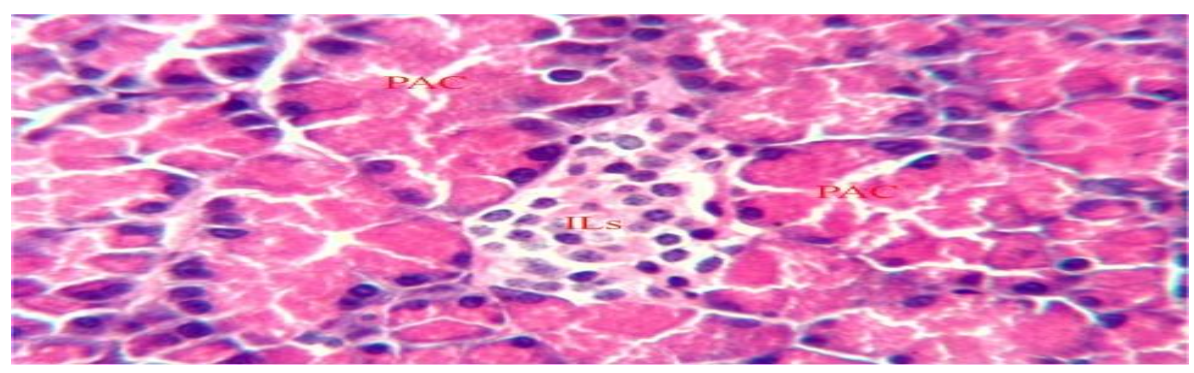

Figure3: Photomicrographs of sections from the pancreatic of G4 adult male albino rats. $\mathrm{H} \& \mathrm{E} \times 640$

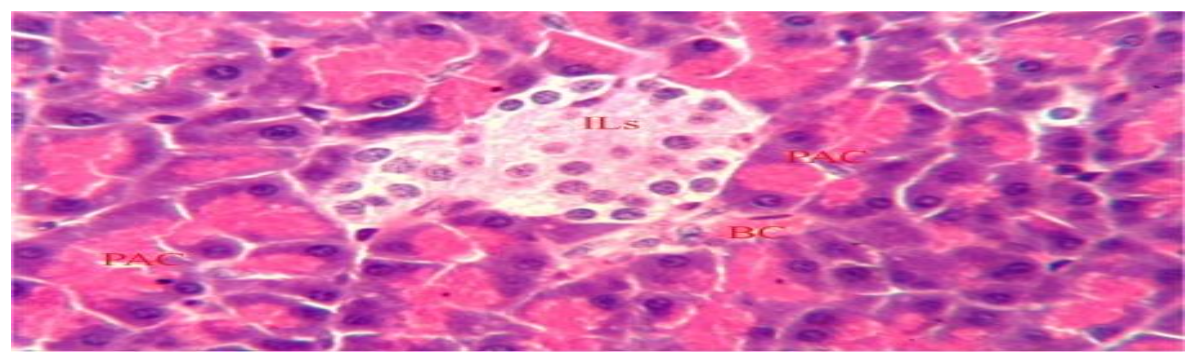

Figure 4: Photomicrographs of sections from the pancreatic of G5 adult male albino rats. $\mathrm{H} \& \mathrm{E} \times 640$. 
Egyptian J. of Nutrition Vol. XXXVI No. 2 (2021)

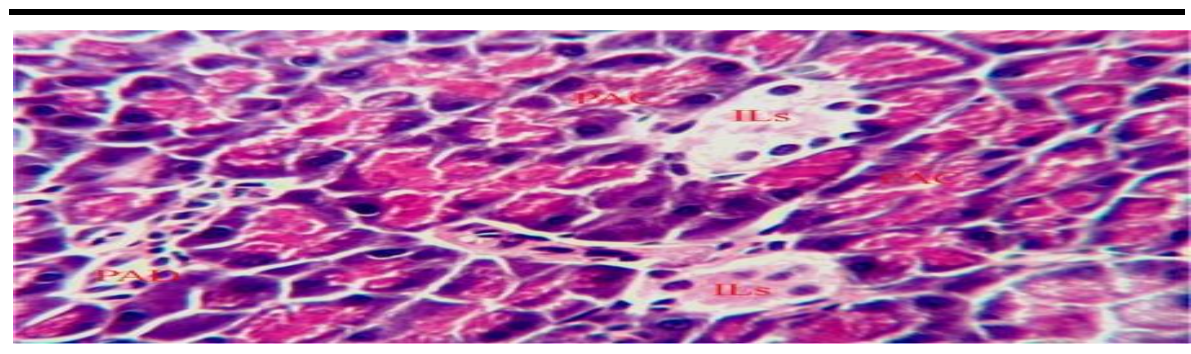

Figure 5: Photomicrographs of sections from the pancreatic of G5 adult male albino rats. .H \& E x640

\section{References}

Abubakar, S.M., Umar, S.A., Alexander, I., Abubakar, N., Abdulazeez, M.A., and Sule, M.S.(2018).

"Evaluation of hypoglycaemic, hypolipidaemic and nontoxic effect of hydro-methanolic extracts of Ziziphus mauritiana, Ziziphus spina christi fruit and glibenclamide on alloxan 


\section{Atwaa E.H. , Hanan A. Radwan, Hanan S. Shalaby and Ghada M. El-Araby}

induced diabetic rats", Journal of Drug Delivery and Therapeutics. 8(3). 82-92.

Aebi, H.(1974).

Catalase In:Bergmeyer HV, editor. Methods in enzymatic analysis. Vol 2, New York: Acadamic press, 17:674-84. AfricanPlantDatabase.2017.[https://www.ville.ge.ch/musinfo/b $\mathrm{d} / \mathrm{cjb}$ /africa/recherche.php].

Ahmed, F. A. M., and Sati, N. M. E. (2018).

Chemotaxonomic study and botanical overview of some Ziziphus spp. in Sudan. Int. Res. J. Biol. Sci. 7(5): 32- 39.

Al-Ghamdi, A.A.M., Manal El-Zohri and Shahat, A.A.(2019).

Hepatoprotective, nephroprotective, anti-amylase, and antiglucosidase effects of Ziziphus spina-christi (L.) against carbon tetrachloride-induced toxicity in rats. Trop J. Pharm .Res., 18(4): 781-790. 
Egyptian J. of Nutrition Vol. XXXVI No. 2 (2021)

Alhakmani, F., Khan, S.A., and Ahmad, A.(2014).

"Determination of total phenol, in-vitro antioxidant and antiinflammatory activity of seeds and fruits of Zizyphus spinachristi grown in Oman", Asian Pacific Journal of Tropical Biomedicine, 4. S656-S660.

Al-hamdani, .M.S., Al-Anbary, E.H., and Ahmed, .M.(2015).

Effect of Lupin (Lupinus albifrons) flour on microbial and sensory properties of local Yoghurt. Advances in Life Science and Technology, 34.1-6.

American Diabetes Association. (2019).

2.Classification and diagnosis of diabetes: standards of medical care in diabetes. Diabetes Care 42, 513-

528.AngiospermPhylogeny.2012.[http://www.mobot.org/MOB $\mathrm{OT} / \mathrm{research} / \mathrm{APweb} /]$.

AOAC. (2007).

Official Methods of Analysis. (18th Ed) Association of Official Analytical Chemists. Maryland. USA.

Aryana, K.J. (2003). 


\section{Atwaa E.H. , Hanan A. Radwan, Hanan S. Shalaby and Ghada M. El-Araby}

Folic acid fortified fat free plain set yoghurts. Int. J. Dairy Technol., 56(4): 219-222.

Asgarpanah, J., and Haghighat, E.(2012).

"Phytochemistry and pharmacologic properties of Ziziphus spina christi (L.) Willd", African journal of pharmacy and pharmacology, 6(31). 2332-2339.

Atwaa, E.H., Eman T. Abou Sayed-Ahmed and Hassan, M. A. A.(2020).

Physicochemical, Microbiological and Sensory Properties of Low Fat Probiotic Yoghurt Fortified with Mango Pulp Fiber Waste as Source of Dietary Fiber. Journal of Food and Dairy Sciences, 11, 9, : 271-276.

Avizeh, R., Najafzadeh, H., Pourmahdi, M., and Mirzaee, M.(2010). "Effect of glibenclamide and fruit extract of Zizyphus spinachristi on alloxan-induced diabetic dogs", The Journal of Applied Research in Veterinary Medicine, 8(2). 109. 2010

Banchroft J., Stevens A., and Turner D. (1996).

Theory and practice of histological techniques. 4th Ed. Churchil Livingstone, NewYork, London, San Francisco, Tokyo. 
Egyptian J. of Nutrition Vol. XXXVI No. 2 (2021)

Bandawane, D.D., Mooliya, S.B., and Jadhav, S.B.(2020).

Protective role of berberine in ameliorating diabetic complications in streptozotocin-high fat diet model in experimental animals. Int J Pharm. Pharm. Sci., 12 (8): 41-48.

Bencheikh, N., Bouhrim, M., Merrouni, I.A., Boutahiri,S , Kharchoufa, L., Addi, M., Tungmunnithum ,D., Hano ,Ch., Eto, B., Legssyer, A., and Elachouri, M.(2021).

Ntihyperlipidemic and Antioxidant Activities of Flavonoid-Rich Extract of Ziziphus lotus (L.) Lam. Fruits. Appl. Sci., 11, 778:213.

Bergmeyer, H.U., and Harder, M. (1986).

A colorimetric method of the determination of serum glutamic oxaloacetic and glutamic pyruvic transaminase, Clin. Biochem., 24: 481-486.

Brand-Williams, W.; Cuvelier, M. E.; and Berset, C.(1995).

Use of a Free Radical Method to Evaluate Antioxidant Activity. Lebenson Wiss Technol., 28, 25-30. 


\section{Atwaa E.H. , Hanan A. Radwan, Hanan S. Shalaby and Ghada M. El-Araby}

Bullard, K. M., Cowie, C. C., Lessem, S. E., Saydah, S. H., Menke,A., and Geiss, L.S.(2018).

Prevalence of diagnosed diabetes in adults by diabetes type

United States 2016. Morb. Mortal. Wkly. Rep., 67, 359-361.

Dabija, A., Codinăa, G.G., Gâtlana, A.M., and Rusu, L.(2018).

Quality assessment of yogurt enriched with different types of fibers. Cyta - Journal of Food, 16, 1, 859-867.

Devi, R., and Sharma, D.K. (2004).

Hypolipidemic effect of different extracts of Clerodendron colebrookianum Walp in normal and high-fat diet fed rats. $J$ Ethnopharmacol, 90:63-68.

Deweerdt, L., and Later, R. (2009).

Mise en place d'un laboratoire de biologie médicale autonome dans un pays en développement.

Doumas, B.T., Perry, B.W., Sasse, E.A. and Straumfjord, J. V, (1973). 
Egyptian J. of Nutrition Vol. XXXVI No. 2 (2021)

Standardization in bilirubin assays: evaluation of selected methods and stability of bilirubin solutions. Clin. Chem., 19:984-993.

El Maaiden, E., El Kharrassi, Y., Moustaid, K., Essamadi, A. K. and Nasser, N. (2019).

Comparative study of phytochemical profile between Ziziphus spina christi and Ziziphus lotus from Morocco. Food Measure, 13(1): 121-130.

Friedewald, W.T., Levi, R.I., and Fredrickson, D.S. (1972).

Estimation of the concentration of low-density lipoproteins cholesterol in plasma without use of the ultracentrifuge. Clin. Chem., 18: 499-502.

\section{Gowanlock dies at 1988",}

Winnipeg Free Press, Thursday, September 29,1988, Winnipeg, Manitoba, Canada, pg 67.

Hamza, N., Berke, B., Cheze, C., Agli, A.N., Robinson, P., and Gin, H.(2010).

Prevention of type 2 diabetes induced by high fat diet in the C- 57BL/6J mouse by two medicinal plants used in traditional 


\section{Atwaa E.H. , Hanan A. Radwan, Hanan S. Shalaby and Ghada M. El-Araby}

treatment of diabetes in the East of Algeria. $J$ Ethnopharmacol; 128:513-8.

Hamza, M., Garba, A., and Ma'Aruf, S.(2015).

"Evaluating the Medicinal and Nutritional Benefits of Nigerian Edible Fruits of Ziziphus jujube and Ziziphus spina-christi Plants". 2015.

Hashem, S.M., and Abd El-Lahot, M. S. (2021).

Utilization of Nabaq Fruit Nutritional Value and Antioxidant Activity in Some Food Products. J. of Food and Dairy Sci., Mansoura Univ., 12 ( 5):111 - 117.

Hemmati, M., Elham Serki , Maryam Gholami, and Reyhane Hoshyar.(2016).

Effects of an ethanolic extract of Berberis vulgaris fruits on hyperglycemia and related gene expression in streptozotocininduced diabetic rats. Clinical Phytoscience, 2:3;1-7.

Henry, R. J. (1974):

Clinical Chemist: Principles and Techniques. 2nd, Edition, Hagerstoun (MD), Harcer, ROW, P. 882. 
Egyptian J. of Nutrition Vol. XXXVI No. 2 (2021)

Hoshyar R, Mahboob Z, and Zarban A.(2015).

The antioxidant and chemical properties of Berberis vulgaris and its cytotoxic effect on human breast carcinoma cells. Cytotechnology. 2015; 1-7. Epub ahead of print].

Houot, O.; Bednawska, M.W.; Zhiri, A and Slest, G. (1985).

Simultaneous Determination of Uric Acid and Creatinine in Plasma by Reversed-phase Liquid Chromatography. Journal of Clinical Chemistry, 31(1):109.

Hu, M. L. (1994).

Measurement of protein thiol groups and glutathione in plasma. Methods Enzymol., 233:380-385.

Jentzsch, A.M.; Bachmann, H.; Furst, P., and Biesalski, H.K.(1996):

Improved analysis of malondialdehyde in human body fluids. Free Radic Biol Med.,20:251-256.

Joshi, D.V., Patil, R.R., and Naik, S.R. (2015).

Hydroalcohol extract of Trigonella foenum-graecum seed attenuates markers of inflammation and oxidative stress while 


\section{Atwaa E.H. , Hanan A. Radwan, Hanan S. Shalaby and Ghada M. El-Araby}

improving exocrine function in diabetic rats. Pharm. Biol., 53: 201-211.

Karr, S. (2017).

Epidemiology and management of hyperlipidemia. Am. J. Manage.Care 23, S139-S148.

Kebary, K.M.K. and Hussein, S.A.(1999).

Manufacture of low fat Zabady using different fat replacers. Acta Alimetaria, 28 (1): 1 - 14.

Khader, S.A., Basma R. El-Khatib and Yasmine E. ElSheikh.(2017).

Effect of Christ's Thorn (Ziziphus Spina- Christi) And Tiger Nut (Cyperusesculentus) Fruitson Liver Disorder In Carbon Tetrachloride Induced Hepatic Rats. Trop J Pharm Res., 18(4): 781-790.

Khan, I., Najeebullah, S., Ali, M., and Shinwari, Z.K.(2016). 
Egyptian J. of Nutrition Vol. XXXVI No. 2 (2021)

Phytopharmacological and ethnomedicinal uses of the Genus Berberis (Berberidaceae): A review. Tropical Journal of Pharmaceutical Research September; 15 (9): 2047-2057.

Koc, M., Taysi, S., Buyukokuroglu, M.E., and Bakan, N. (2003). Melatonin protects rat liver against irradiation-induced oxidative injury. J. Radiat. Res., 44:211-215.

Končić, M.Z., Kremer, D., Karlović, K., and Kosalec, I.(2010).

Evaluation of antioxidant activities and phenolic content of Berberis vulgaris L. and Berberis croatica Horvat. Food Chem Toxicol.; 48:2176-80.

Laličić-Petronijević, J., Komes, D., Gorjanović, S., BelščakCvitanović, A.,, Pezo, L., Pastor, F., Ostojić, S., PopovRaljić, J., and Sužnjević, D. (2016).

Content of total phenolics, flavan-3-ols and proanthocyanidins, oxidative stability and antioxidant capacity of chocolate during storage. Food Technology and Biotechnology, 54 (1): 13-20.

Mensor, L. L.; Menezes, F. S.; Leitao, G. G.; Reis, A. S.; Santos, T. C. d.; Coube, C. S.; and Leitao, S. G.(2001). 


\section{Atwaa E.H. , Hanan A. Radwan, Hanan S. Shalaby and Ghada M. El-Araby}

Screening of Brazilian Plant Extracts for Antioxidant Activity by the Use of DPPH Free Radical Method. Phytother. Res.,15, 127-130.

\section{Michel, C.G., Nesseem, D.I., and Ismail, M.F.(2011).}

"Anti-diabetic activity and stability study of the formulated leaf extract of Zizyphus spina-christi (L.) Willd with the influence of seasonal variation", Journal of ethnopharmacology. 133(1). 53-62.

Moss, D. W. (1982):

Alkaline Phosphates isoenzymes, Clin. Chem., 28:2007-2016.

Nair, G.G., and Nair, C.K. (2015).

Radioprotective effects of Gallic acid in mice. Bio. Med. Res. Int., 953079.

Nelson, J.A., and Trout, G.H. (1981).

Judging of dairy products, 4th Ed. INC Westport, Academic Press. 345-567.

Page, A. L., Miller, R. H. And Keeney, D. R., (1992). 
Egyptian J. of Nutrition Vol. XXXVI No. 2 (2021)

Methods of soil analysis, part-2 chemical and microbial properties, 2nd edn. Am. Soc. Agronomy and Soil Sci. Soc. Am., Inc., Publs., Madison, Wasconsis, USA.

Pakseresht, S., Tehrani, M.M., and Razavi, S.M.A.(2019).

Optimization of low-fat set-type yoghurt: effect of altered whey protein to casein ratio, fat content and microbial transglutaminase on rheological and sensorial properties Food Sci .Technol., 54(8):2351-2360.

Pankaj, G. J., Savita, D. P., Nitin, G. H., Manoj, V. G., and Sanjay J. S. (2010).

Hypolipidemic activity of Moringa oleifera Lam., Moringaceae, on high fat diet induced hyperlipidemia in albino rats. Brazilian Journal of Pharmacognosy: *Tel: +91 2563 255189, Fax: +91 2563251808.

Reeves, P.G., Nielsen, F.H., and Fahey, G.C. (1993).

AIN-93 purified diets for laboratory rodents: final report of the American Institute of Nutrition ad hoc writing committee on the reformulation of the AIN-76A rodent diet. J. Nutrition, 123(11):1939-1951.

Saaty, A.H.(2019). 


\section{Atwaa E.H. , Hanan A. Radwan, Hanan S. Shalaby and Ghada M. El-Araby}

Review of the Nutritional Values and Biological Activities of Ziziphus Spina-christi (Sidr) Plant Extract. American Journal of Food and Nutrition, 7(4): 166-172.

Saied, A.S., Gebauer, J., Hammer, K., and Buerkert, A.(2008).

"Ziziphus spina-christi (L.) Willd.: a multipurpose fruit tree", Genetic Resources and Crop Evolution. 55(7). 929-937.

SAS, (1996).

SAS/ Stat Users Guide: Statistics, System for Windows, version 4.10 (release 6.12 TS level 0020), SAS Inst., Inc. Cary, North Carolina, USA.

Srinivasan K, Viswanad B, Asrat L, Kaul CL, and Ramarao P.(2005)

Combination of high-fat diet-fed and low-dose streptozotocintreated rat: a model for type 2 diabetes and pharmacological screening. Pharmacol Res; 52:313-20.

Steel, R., Torrie, J. and Dickey, D. (1997).

Principles and Procedures of Statistics: A Biometrical Approach. 3rd Ed, McGraw-Hill, New York, NY. 
Egyptian J. of Nutrition Vol. XXXVI No. 2 (2021)

Stumvoll, M., Goldstein, B.J., and Van Haeften, T.W.(2005).

Type 2 diabetes: principles of pathogenesis and therapy. Lancet; 365:1333-46.

Temerk, H., Salem, W., Sayed, W., and Hassan, F.(2017).

"Antibacterial effect of phytochemial extracts from Ziziphusspina christi against some pathogenic bacteria", Egyptian Journal of Botany. 57(3). 595-604. 2017.

Thomas, A., Schänzer,, W., and Thevis, M. (2014).

Determination of human insulin and its analogues in human blood using liquid chromatography coupled to ion mobility mass spectrometry (LC-IM-MS). Drug Testing and Analysis. 6: 1125-1132.

Tiertz, N. W. (1976):

Fundamental of clinical chemistry, philade Iphia, (2) W.B., PP.53-56.

Trinder P. (1969).

Determination of Glucose in Blood Using Glucose Oxidase with an Alternative Oxygen Acceptor.Ann.Clin. Biochem., 6(1):24-33.

Weidner, S., Powałka, A., Karamać, M., and Amarowicz, R.(2012). 


\section{Atwaa E.H. , Hanan A. Radwan, Hanan S. Shalaby and Ghada M. El-Araby}

"Extracts of phenolic compounds from seeds of three wild grapevines-Comparison of their antioxidant activities and the content of phenolic compounds", International journal of molecular sciences, 13(3).3444-3457.

While, B. A.; Erickson, M.M. and Steven, S. A. (1970): Chemistry for Medical Theologies Ts. 3Rd Ed., C.V. Mosby company saint Louis, USA, P.662.

WHO (2016).

World Health Organization. World health statistics. Geneva: World Health Organization.

Yossef, H., Khedr, A., and Mahran, M., (2011).

"Hepatoprotective and antioxidant effects of Zizyphus spinachristi fruits on carbon tetrachloride induced hepatotoxicity in rats", Nature and Science, 9.1-7.

Zarina, Z., and Tan, S.Y. (2013).

Determination of flavonoids in Citrus grandis (Pomelo) peels and their inhibition activity on lipid peroxidation in fish tissue. International Food Research Journal, 20: 313- 317. 
Egyptian J. of Nutrition Vol. XXXVI No. 2 (2021)

Zheng, T., Shu, G., Yang, Z., Mo, S., Zhao, Y., and Mei, Z.(2012).

Antidiabetic effect of total saponins from Entadaphas eoloides (L.) Merr. in type 2 diabetic rats. J Ethnopharmacol 2012;139:814-21. 


\section{Atwaa E.H. , Hanan A. Radwan, Hanan S. Shalaby and Ghada M. El-Araby}

\section{الفعل العلاجي للزبادي المنخفض الدهن المدعم بمسحوق فاكهة السدر على بلى بلفئ

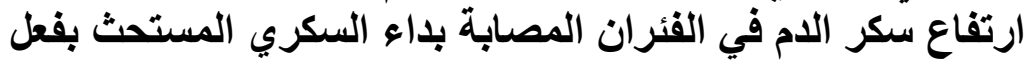

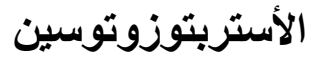 \\ السيد حسن عطوة' - حنان احمد رضوان ب - حنان سعيد شلبي

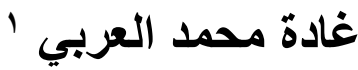

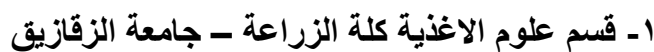

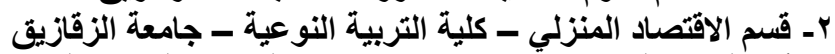

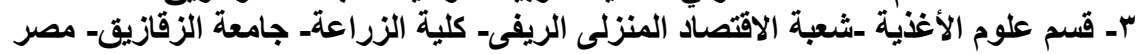

\section{الملخص}

تحتوي فاكهة السدر على تركيبة غنية من المكونات النشطة بيولوجيًا مثل الفينول

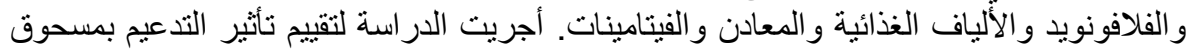

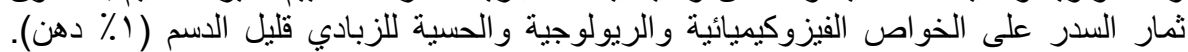

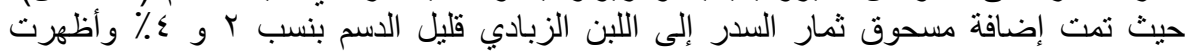

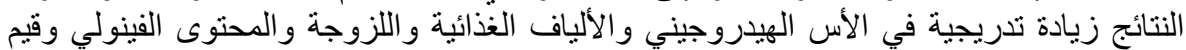

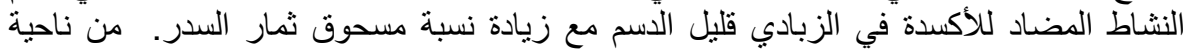

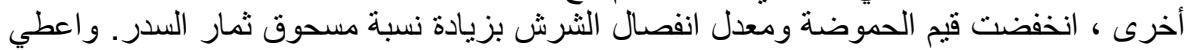

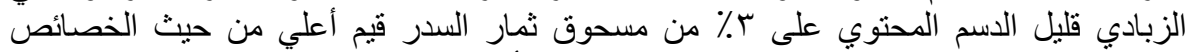

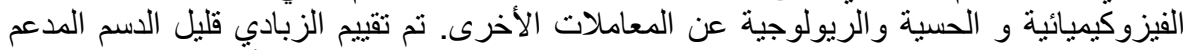

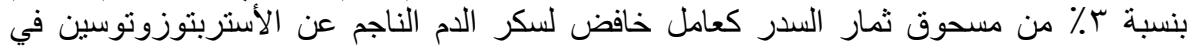

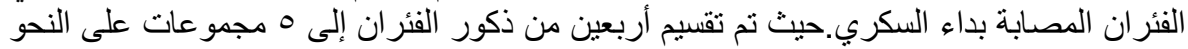

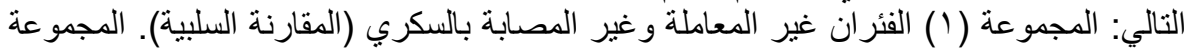

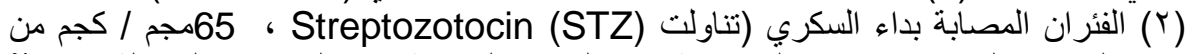

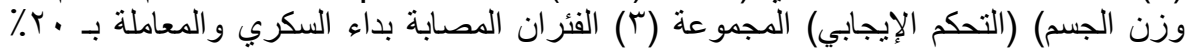

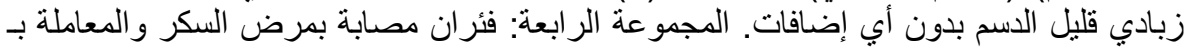

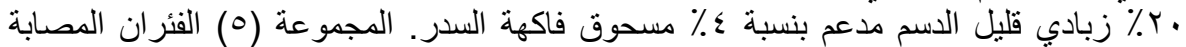

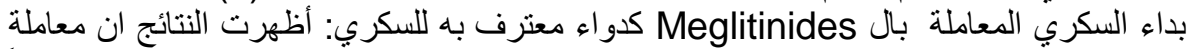

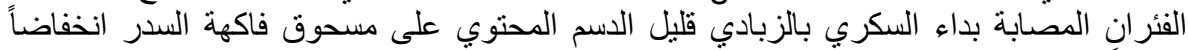
معنوياً (0.001) p p) في مسنويات السكر في الدم ، المالونديالائيهيد (MDA) ، البروتين الدهني 
Egyptian J. of Nutrition Vol. XXXVI No. 2 (2021)

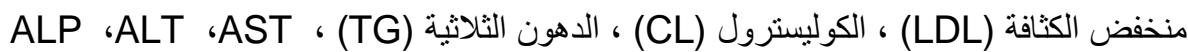

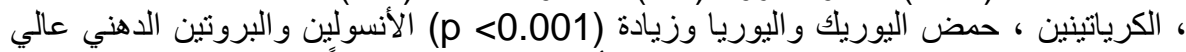

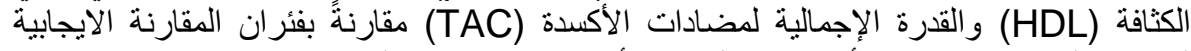

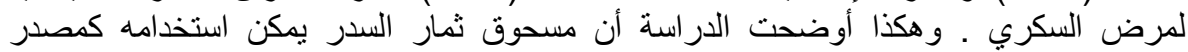

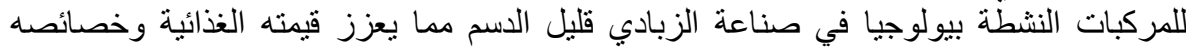

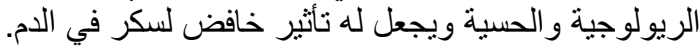

